\title{
Looking for work: youth, masculine disadvantage and precarious employment in post-millennium England
}

\author{
Linda McDowell \\ School of Geography and the Environment \\ University of Oxford
}

Oxford OX1 3QY

Linda.mcdowell@geog.ox.ac.uk

ORCiD 0001-7888-0886

\begin{abstract}
The changing nature of youth (under)employment in England since the start of the new millennium is explored through a comparative analysis of three cohorts of young working class white men searching for work in English towns between 2001 and 2017. Labour market changes, including the rise of precarious work and forms of self-employment, as well as increasing inequality and cuts in youth services since the financial crisis in 2008, are having a serious impact on the least qualified young men. However, changes in the nature of employment at the bottom end of the service suggest the re-evaluation of earlier claims about the relative disadvantage of (some) young men.
\end{abstract}

Key words: young men, employment, deference, masculinity, austerity, platform economy

\section{Introduction}

Labour market restructuring since the start of the new millennium, especially the rise of precarious employment, including zero hours' contracts and various forms of pseudo self-employment, places working class people in an increasingly disadvantaged position in their search for waged work. This affects their ability to secure an adequate standard of living and some degree of independence, as well as their sense of self-worth. Drawing on three studies of young working class men, the ways in which young men have faced increasingly difficult circumstances over the first decade and a half of the twenty-first century as precarious work becomes more common are addressed. Both young men themselves and working class families are facing circumstances that make access to decent work that provides sufficient income 
to achieve independent living and support dependents increasingly problematic. Tightening social security regulations, cuts in benefit entitlements and in payment levels, closure of youth services and limited access to housing combine to produce a cold new world for young men hoping to find employment and achieve at least one of the markers of adult status.

The argument proceeds as follows. A summary of young men's disadvantage in an economy dominated at the bottom end by interactive service employment is outlined, developing a critique of previous claims about the disadvantage of young working class men, whose performances of a particular version of masculinity inhibit their employment in the sort of interactive service jobs that demand deference. Many working class young men adopt a street-wise aggressive version of masculinity, that previous studies have shown places them at a relative disadvantage compared to young women in their search for waged work (Ilan 2013; Nixon 2009). The connections between what Connell (2000) termed 'protest masculinity' and the changing nature of employment at the bottom end of the labour market are then illustrated though the stories of six young men's job search, preceded by an outline of the study design, and issues about positionality and the analysis of oral narratives.

\section{The relative disadvantage of young men in service economies}

It is now well-established in youth studies and labour market analyses that many working class youths in advanced industrial economies no longer experience a linear transition from school into employment, but cycle in and out of shortterm, precarious work, making little progress into a more stable jobs (Bourgois 1995; France 2008; Furlong 2006; McDowell 2003; Newman 1999: Nixon 2017). In most British towns and cities, the work available to the least well qualified and less skilled young people is in poorly paid jobs in the service sector. These jobs typically have been in feminised, low paid and interactive positions, requiring face-to -face contact with customers. Contracts are often impermanent, employment is frequently part-time, and sometimes involves antisocial hours. It is here that young people, men as well as women, without formal credentials have to search for work.

It has been widely argued that young working-class men are particularly disadvantaged in the competition for these position. Young men are often deemed not to embody the characteristics and attitudes perceived as appropriate in the interactive service sector in which deference, self-presentation and the performance of servility and civility are prized (Ashton et al 1990; Bourgois 1995; Fine and Weiss 1998; France 2008, 2016; Furlong 2006; MacDonald and Marsh 2001; McDowell 2003, 2012; Nayak 2006, Newman 1999; Nixon 2017). 
These are jobs in which the performance of a particular version of an embodied subjectivity is required, variously termed emotional (Hochschild 1983), aesthetic (Williams and Connell 2010) and affective labour (Farrugia et al 2018), involving the manipulation of desire through the seduction of the customer (Bauman 1998): skills that often contradict the typical performance of youthful working class masculinity.

White working class young men have also been identified as those least likely to proceed into higher education. In a labour market where qualifications are the entry requirement for a growing proportion of jobs, these men are vulnerable to competition from other applicants for entry level positions, including older women returning to the workforce after having children. The version of a 'hard' working class masculinity previously valued by prospective employers, as Willis (1977) argued, is now more likely to result in young men's disqualification from service employment all together or their confinement to casual employment in jobs such as shelf stacking in the retail sector, warehouse jobs or in the hospitality sector in fast food outlets (McDowell 2003, Newman 1999) and in bars, pubs and clubs (Farrugia et al 2018; Monaghan 2002).

These types of waged work have become an increasingly significant part of the bottom end of the labour market for at least three decades. Since the financial crisis in 2008 , however, and introduction of austerity policies by the coalition government elected in 2010 , the prospects of unskilled young people achieving a reasonable standard of living through waged work have reduced even further. Although the UK has recovered somewhat from the crisis, it remains a low growth economy, as austerity followed crisis (Farnsworth 2011, Grimshaw and Rubery 2012, Lupton et al 2016). In 2017 the UK was at the bottom of the ranking $\mathrm{G} 7$ countries in terms of growth in gross domestic product. Living standards have not risen, especially for the least well-off, as there has been no real wage growth in the UK economy since 2007. State benefits to support those in work have been reduced and wider cuts in the public sector have seriously eroded the provision of youth services (Hughes et al 2014, Youndell and McGimpsey 2015).

The net effect has been the creation of a harder and more unequal world for young men searching for work, not only in the UK (Bloodworth 2018; Whitman 2017), but elsewhere in Europe (Antonucci et al 2015) and in the USA (Besen-Cassino 2014; Silva 2013). Across the time period under consideration here - a decade and a half at the beginning of the $21^{\text {st }}$ century - rates of unemployment for young people (aged 16-24) in the UK have consistently been higher than overall rates. In 2015, for example, rates for young people were 
almost three times those for older workers (14.4\% compared to 5.7\%). At its peak in 2014, $21 \%$ of young people were workless when, as Giazitzoglu (2014) has suggested, it seemed not unreasonable to suggest that for some the search for waged work was so dispiriting that a rational decision might have been to stop looking and turn to other ways of filling their days.

\section{Blaming the victim}

If the decision not to seek work may have been rational for individuals, the discursive and rhetorical construction of young people without employment is different. Moral judgements about class, youth and self-worth have stigmatising effects (Bourdieu 1997; Jones 2012; Sayer 2005; Skeggs 2004) and although decent work has become increasingly inaccessible to working class youth, the problem of un(der)employment is typically explained in individualized terms. Workless youth themselves are blamed for their failure to find a job (MacDonald and Marsh 2001; MacDonald et al. 2010). Across the decade and a half of interest here, young people have been constructed as 'skivers', unwilling to become 'strivers': terms 'popularised' by the former Conservative Chancellor of the Exchequer, George Osborne in a deplorable interview on the UK radio programme in 2012 (October $8^{\text {th }}$ ). Popular accounts, political discourse and, to an extent, youth intervention schemes represent working class young people as lacking aspiration and unwilling to work, ignoring the reality of labour market opportunities and the demands entailed by access to waged employment (Valentine and Harris 2014). The result of this stigmatization may be paradoxical. As Bourdieu (1999) argued, with nothing to lose, young men may make a virtue of necessity, exaggerating the attributes that exclude them and resisting the label of failure. Others may internalise the rhetoric of failure and lack of self-worth. However, as the narratives presented below demonstrate, young men are active agents and able to both resist and conform at the same time, often with a clear-sighted view of their representation by the media and politicians.

\section{Insecure employment}

Over the decade and a half, however, there has been a significant change in the nature of low waged employment, in its contractual form and in both the personal attributes and the material possessions demanded for successful entry. Although overall rates of youth unemployment have fallen since 2014, underemployment has become more significant. New forms of employment contracts and reduced hours of work at the bottom end of the labour market are resulting in growing numbers of jobs that are less than full time and increasingly insecure or precarious (MacDonald 2016). Zero hour contracts, part-time and casual 
employment and most significantly forms of self-employment have increased. In total, 4.7 million UK workers were self- employed at the end of 2017. As the Taylor et al report (2017) on new forms of employment documented, the distinction between being self-employed, a contractor, a worker and an employee is crucial in the current era in excluding many from the rights and benefits of secure employment.

One of the most notable changes has been the expansion of the so-called platform or gig economy (Prassl 2018), in which growing numbers of people participate, driving cars (for Uber, for example) and vans (for Hermes or DPD), delivering parcels and official documents (numerous cycle courier firms) as well as restaurant food for consumers to eat at home (for Deliveroo). What is significant about this type of work for the argument here is its dominance by (often young) men, in which some of the stereotypical virtues of embodied masculinity - speed, endurance, risk taking and geographical orientation skills (Day 2016) - are highly valed. These sorts of jobs, especially self-employment, also demand that the participants are able to keep records and file their own tax returns. For others on casual contracts, the new benefit system (universal credit) demands computer literacy, regular reporting of hours and wages and ensuring appointments with advisers are kept. When in work, employed through a high tech platform, a smart phone is a basic requirement, as is a bicycle, motor cycle or a car. Further, for many jobs bearing the start-up costs of the uniform and other equipment is essential (Bloodworth 2018, Day 2016). It is in this new form of employment, as shown later through two narratives, that masculinity may confer advantage, but which also constructs a new divide between young working class men, based on their differential ability to acquire the skills demanded in the gig economy. Before turning to the six narratives, the methods and analysis are outlined.

\section{Research design and location: three places and six stories}

The changing nature of 'poor work' (Toynbee 2003) and its association with the social construction of masculinity is explored through six young men's narratives of searching for and cycling in and out of employment. These men lived in Cambridge, Swindon and Hastings, towns of similar sizes in southern half of England that seldom feature in analyses of poverty and inequality. At the time of the conversations, each town had significant youth unemployment. Cambridge was and remains one of the most places with the highest degree of income inequality (Crang and Martin 1991; Kirk and Cotton 2012); Swindon had lost employment in a key sector (the car industry) (Rootham and McDowell 
2017) and Hastings has recently been identified as amongst the most deprived towns in the UK (Corfe 2017).

The six men whose stories are presented here were part of larger-scale studies focussing on the social construction of masculinities and the experience of worklessness in the context of service sector growth, based on semistructured qualitative interviews with 65 un(der)employed young men between the ages of 16 and 25. In Cambridge the interviews were carried out in 2001 and 2002, and each young man was interviewed three times (McDowell 2003). In Swindon, the men were first interviewed in 2011, and a smaller subset of participants, were re-interviewed a year later (Hardgrove et al 2015). In Hastings, interviews were carried out in late 2017. A small number of key informant interviews were also undertaken with employers and youth service providers in each town.

A narrative approach was adopted in which the assumption behind these conversations is that knowledge is socially constructed and that individuals are constantly involved in making sense of their world, interpreting and reinterpreting experiences, and understanding them as stories (Gubruim and Holstein 2009). Narrative not only reflects but also constructs experiences of labour market changes. Like Bourdieu (1990), Connell (2000) also argued that young working class men often construct a narrative identity based on a rejection of the world of work, exaggerating the very attributes on which their exclusion is based. These may include an aggressively masculine performance, a devil may care attitude or forms of bodily adornment unacceptable to potential employees, as well as 'talking the talk' and appearing 'hard'.

Adopting a narrative approach, however, was not straight-forward. Young working class men, especially those without employment, are often not easy identify or to persuade to talk. Some young men without waged work are suspicious of apparently affluent academics. Others are unused to articulating their feelings or reluctant to talk about what they may regard as their own failure. In all three places the interviews were undertaken by women, all of us able-bodied, and middle class; all but one young, all but one white, all but one heterosexual, although it is difficult to assesses the effects of these differences. The young men were all white, from working class backgrounds and, if volunteered, identified as heterosexual and cisgender. Potential participants were approached in different venues, from hang-out spots in the towns, to youth clubs and projects for the unemployed. Young men who agreed to participate were encouraged to introduce their friends, and all of them were paid a small sum as a token of gratitude. 
The conversations were recorded when permission was given, which was in almost all cases and, when it was not, reconstructed later on the basis of notes taken at the time. The participants were encouraged to talk freely about their lives, in the belief that experiences make sense when linked to past events. A common trope, however, is that of a journey or a transition from adolescence to adulthood, marked by the achievement of independent status (Brooks 2009). Negative comments on, for example sexist or racist remarks, or when information was volunteered about involvement in semi-legal activities were not remarked on. The interviews were transcribed and analysed thematically, listening for external and internal voices, drawing on the listening guide developed by feminist psychologists (Gilligan et al 2003). Pseudonyms were allocated to maintain confidentiality.

\section{Narratives of continuity and change}

In each of the three places, two narratives were selected to illustrate the search for work across the first fifteen years of the new millennium. Through a crosssectional analysis, based on the portraits of young men at different dates (and see Jeffrey and Dyson 2008), the aim is to capture both continuities and changes in the prospects for young working class men. The structural circumstances facing school leavers without qualifications have barely changed, despite the growth of more precarious jobs as noted earlier, and popular media and political/policy stereotypes of young men as idlers or lacking moral fibre have also proved a consistent rhetorical construction across the decade and a half. As the narratives presented in the next section reveal, labour market and income inequality and the symbolic violence enacted on and often bought into by working class young men continue to position them at the bottom of the hierarchy of eligibility, if not completely excluding them from waged work. As the narratives also demonstrate, uncertain work, worklessness and the benefit cuts currently being introduced reduce young men's ability to construct an alternative identity through consumption, and/or through the development of a form of street-based social capital that confers a degree of status among peers (Ilan 2013). Without some of the markers of status - a phone, certain clothes young men find not only a job but also a sense of their social worth hard to maintain.

\section{1: Inequality in Cambridge}

Cambridge in 2001 was a booming city for some: employment had expanded for the well-educated in hi- tech industries and in the university (Kirk and Cotton 2012) but at the bottom end of the labour market, the consumer service industries and tourism had created growing numbers of poorly paid interactive 
jobs, in a city that had always had a sizeable proportion of 'poor' jobs (Crang and Martin 1991, McDowell 2003). For young working class men, leaving school and looking for work, employment opportunities were not easy to access. Their educational and social capital made them ineligible for well-paid work and their social skills and aptitudes, as well as their own preferences for 'men's work', excluded them from many of the low-paid positions. At the start of the millennium, the arguments about young men's relative disadvantage compared to their female peers were well-founded.

Here Wayne and then Guy explain their aspirations and search for work:

I want to be a mechanic. I have always been into cars and I have always been better with my hands.

It has to be a real job, like; you know what I mean. Shop work is for girls.

Despite their preference for work coded as masculine, both of them found that they had to accept a variety of lower status jobs in the service sector, cycling in and out of casual jobs, often on a short term basis. Precarity (Standing 2011) was already well-established in this city. Over the period of eighteen months, Guy, for example, worked as a security guard, as a contract cleaner in the Science Park, as an assistant in a dry cleaner's, as a kitchen-hand in a restaurant and as handyman and waiter in a fast food restaurant, where as he explained 'it all went pear shaped'. He had no employment contract and was sacked after a few weeks. His stint in the kitchen was even shorter. He left after a few days. 'I hated it to be honest. It's hard work in kitchens.; it really is hard work. Its non-stop'.

Despite his uneven record, what was noticeable about Guy was that he continued to look for work. He may not have lasted long in any one job, but he was seldom unemployed. He accepted that his uncertain employment position was his own fault as he had not worked hard at school:

I took the wrong turn at school. I didn't turn up for lessons. School was just a doddle; it was, for me, a big laugh. The teachers probably just gave up on me.

However, he does not fit the stereotype of a skiver or layabout. He was able to make ends meet, pay his mother a small sum for board and lodging and enjoy a full social life. At the start of the new millennium, casual jobs in a booming city like Cambridge were relatively easy to obtain, especially if, like Guy, you were personable and talkative. It was not hard to believe Guy when he suggested he could talk himself into almost any job. What he less successful at was holding on to it. 
Like Guy, Wayne also had several casual jobs in the retail and hospitality sectors. However, some months after leaving school, Wayne succeeded in finding acceptable 'men's work'. He secured a building trades apprenticeship, involving three 'hands-on' days learning the trade and two days in college. He found the college work a struggle - 'It's the college stuff. I'd rather be at work doing practical things, you know. At college I don't like the writing side of it' but he was determined to persevere: 'I am sorted now. I really am'. He too blamed himself for lack of effort at school:

I mean at school I used to muck about. I fought a lot and I didn't never do no work, but now I am out at work and I know what I am doing it's all right.

The building trade, however, is notoriously cyclical as well as physically demanding, and although Wayne was able to construct an optimistic version of a working class career in 2002, ultimately, without economic and social capital, it is likely that he was entering a dead-end job rather than a career path.

Nevertheless, both men, and the wider cohort to which they belonged, were not pessimistic or even resigned about their future. They may have blamed themselves for poor school attendance but jobs seemed to be within their reach. By 2011 in Swindon, life seemed rather different.

\section{1: Hanging on in Swindon}

In 2011 life in England, especially for the less affluent, was harder. After the 2007-8 financial crash and the deep cuts introduced by the coalition

Government's austerity programme from 2010, economic confidence was low, unemployment rates rising and cuts in income support for the workless were in train. Furthermore, after the accession of twelve new states into the European Union between 2004 and 2010, over a million people had moved to the UK in search of work and competition between migrants and 'locals' was evident in the town (Rootham and McDowell 2017). Young white working class men found it difficult to walk into temporary work by inquiring in shops and restaurants, as Guy had done a decade earlier, instead looking both online and registering with employment agencies. Alfie, for example, had been working for the local council collecting garden refuse, initially on a casual contract. $\mathrm{He}$ typically worked between 7.30am and 3pm, five days a week.

It wasn't too bad, once you learned the ropes but I hated getting up so early. It's hard work, running around doing hard work for seven hours and I got fit, but it's not that nice smelling, to be honest, but you get used to it. 
After five months, however, the council sacked him and so he was looking for work again, registering at several employment agencies, as well as dropping off applications at several large employers.

I want a permanent job, maybe shop work but at nights. I don't like dealing with customers. I've applied to the Co-op and drop in once a week to ask the managers if there any availabilities. I've also applied to B\&Q warehouse, and Argos.

And like the young men in Cambridge, Alfie explained 'I really want to work as a car mechanic'. However, as he added on a note of resignation, 'there are no jobs'.

Joshua too used employment agencies to find work. He had worked as a contract employee for numerous agencies in different jobs, in the main packing in warehouses.

My first job was canvassing for Safe Style Windows. It's like a cold calling company where you knock on doors. It's quite bad actually. I didn't do too bad at it but it wasn't really my thing. You got a minimum wage and a commission but it wasn't enough for me so I decided to leave.

He then worked for DHL, a delivery company.

I was just like a warehouse operative, picking items, labelling them, putting them in the right place. That lasted around five months and that was also agency, weekly pay and stuff. It was a contract from September to Christmas, and after January they let me go.

His next job was similar, working at a warehouse, but he was sacked for being late for a shift.

I was picking and packing parts for Honda car seats. I got it through a recruitment agency, putting car seats into cages, moving them to the other side of the warehouse and that and really easy for the money. It's a shame to lose a job like that. It wasn't high demand; it was quite easy. There was no-one saying "come on, do this". You have a limit and you get on with your own time. I am just looking for more work now because I don't like not working. I like to work.

Both men mentioned difficult family lives: for one an alcoholic father, for the other financial pressures at home and for both of them periods of living in a 
hostel. They also mentioned competition from Polish men, who, in their view, were willing both to work harder and to work for lower wages, reflecting commonly-held stereotypes at the time. But, just as in Cambridge, these two young men also regretted what they saw as their time-wasting in school. They were less optimistic than Guy and Wayne, reporting feelings of resignation or quiet despair about not being able to achieve what they regarded as an acceptable version of successful masculinity.

\section{7: Losing out in Hastings}

Although Hastings, a town on the south coast of England, is only 60 miles from London, 90 minutes on the train, it feels isolated and deprived, with a low waged service sector dominated by casual employment in the declining tourist trade. It has problems of youth homelessness and of drug taking.

Ed, interviewed at a drop-in centre for unemployed youth, was 19 and, like the men in Cambridge and Swindon, had held a series of bottom-end jobs. These included more obviously male-coded jobs involving embodied effort and strength, such as plastering and general labouring. He was a casual worker, paid by cash in hand. He had no contract, and paid no tax or national insurance. Once this work finished, he went to the job centre to see if he was eligible for benefits.

I got to the job centre and I went to sign on and now I do little bits of work with my older brother because he's got a business down here. He goes to abandoned houses that's got loads of furniture and that and takes down all the stuff like the stud boards and knocks them down and the carpets, stuff like that really. He clears the houses too of furniture and then we just take it to the dump.

Before this job, Ed had left Hastings to work with a peripatetic fun fair over the summer months. When talking about this experience he became more animated.

People from the fair come down every year and they put up you know the rides and that and where we go up there every year, they pretty much gave us a job. They said if we wanted to me and my mate could go up and tour with them so we said 'yeah, all right we'll give it a go'.

We had to put up all the rides, put them up and then take them down and then mind the rides when people go on it. It was probably one of the best things I've done in my life. I've never actually done anything like that. I've never left my family like that. We travelled with them for three 
months but then it got a bit too much and obviously we were missing our family and stuff so decided to come back.

Ed returned to Hastings to find his mother had evicted him from the family home and at the time of the conversation, he was sleeping on the sofa at his sister's house and looking for work. As he recognised 'there's not really a lot out there to be honest but if you wanted to find a job urgently probably the best thing to do would be to look in shops and that' but, he continued 'that's not for me'. For these men even the hope of regular work as a mechanic or other malecoded position was unrealistic.

Kai, 19 too, was also homeless. He also shared his experiences with drug taking, mental illness, debt and crime, talking about his difficulties in school, family imprisonment and his problems finding work. He too ascribed his problems in the labour market to his difficult school career and, like Guy and Wayne, regretted lost opportunities.

I just kind of didn't like school but now I just kind of wish I didn't fuck it up because I could of got like actual GCSEs and got like a proper job but I find that hard because I've got like learning difficulties - like special like needs; it makes me stressed and I get kicked out of the classroom and excluded.

He was later expelled for a drug offence and then continued to find trouble, being arrested for stealing bicycles, for which he had to undertake unpaid community service and serve 18 months' probation. He then became involved in drug dealing and, with no sense of blaming anyone but himself, suggested that 'like my life is a bit shit but it's my fault for doing it this way because I could've said no at the beginning'.

One of the major changes over the fifteen years has been in the structure of the benefit system and its movement to a largely computer-based method of application as well as regular attendance at meeting with an 'advisor' at a job centre. Kai was unemployed and so was trying to claim universal credit, but the system demands a claimant not only logs online regularly but also keeps records of hours of job search. It is almost impossible for someone like Kai who not only has literacy issues but has no access to a personal computer:

Yeah, normally you'd get given a book but now on universal credit you have to do it online. I haven't got benefits at the moment because it's been sanctioned because I forgot to go to one of the meetings.

The only job he had had since leaving school was as a labourer, digging trenches and filling them with hard core for a firm tarmacking drive. It was cash 
in hand initially, but the firm then tried to establish Kai as a self-employed worker. However, the paper work defeated him and he was laid off after less than a month.

Kai, like Alfie in Swindon, felt ill-equipped for customer-facing work, although he knew this was a disadvantage in gaining work in a town like Hastings where interactive service employment dominated.

I can't go into a shop and like hand out cv and stuff because too many people I get nervous and stuff. If it was over the phone I'd do it but I'd have to go into the shop and then I'd be like 'agh, I don't know you, don't know you, oh shit' ... that's the thing I'm a bit worried about it, just in case they think different about me and just like makes me more selfconscious.

I wanna start a job. I've been looking. I text Asda, Morrisons and Tescos for a night shift because that's mainly the time I get in trouble because I ain't got nothing to do. So if I do, what's it called, warehouse work at night-time at least I know I'll be off the streets and during the day I can be indoors or sleeping or doing something in the town.

As he rather disarmingly added, 'at the moment I just hang around causing mayhem like'.

Of the six interviewees, it was Ed and Kai who were closest to the stereotypical working class youth described by Connell, exaggerating their 'hardness' and outsider status and so enhancing their ineligibility for any sort of employment involving customer interactions and service. They regretted messing about in school and typically suggested that if anyone was to blame for their current circumstances, it was themselves. However, it was also evident from Kai's narrative that he had a clear understanding of how learning difficulties disadvantaged him in gaining interactive employment. They had no sense, however, of the structural circumstances that contributed to their exclusion from employment.

As I argued initially, one of the most noticeable changes in the nature of low waged work in the most recent period has been the rise of the platform economy, where apparently 'flexible' work is available for self-employed young people, including cycle couriering and fast food delivery. This is not an entirely new form of employment, in the main for young men, although it has increased in significance. Significantly it is highly regulated through surveillance by accessing the hi-tech platform (Fleming 2017; Healy et al 2017, Prassl 2018). For the young men interviewed in Hastings, however, this type of 
work was inaccessible, despite its association with many of the attributes of protest masculinity. Indeed, the predominantly workless young men there found themselves at a particular disadvantage in the competition for gig economy jobs which proved out of their reach. They seldom owned a mobile phone, or if they did theft, loss or pawning it meant a phone never stayed in their hands for long. None of them owned a bicycle, let alone a car, and the layout on the core elements of a uniform, necessary for a job with, for example, Deliveroo, was beyond their financial reach.

The low-paid and insecure jobs in the gig economy, which are not in any sense particularly desirable, seem to be being captured by a more organised and less deprived fraction of the working class, and indeed by middle class students, working to pay off loans, and other young middle class men before starting a permanent job or taking time out from a professional position (Sayarer 2016). Jon Day, now an academic at Kings College London and author of Cyclogeography (2015) with its references to the Situationists and flaneurs, is a good example. As he noted ( $\mathrm{p} 25$ ), the cycle couriers he worked with were young, male and often overeducated for the job. Furthermore, the entrepreneurial skills needed initially to register as a gig worker and daily to upload the app, record the jobs, deliver the goods and claim payment, were beyond the capabilities of the young men trapped in worklessness and, too often, homelessness. Even where such jobs within reach, self-employed workers have to file tax returns, and during periods of unemployment or low wages claim benefits. Recent research from the Policy in Practice Consultancy has shown that the regulations of the Universal Credit system disadvantage gig economy workers who earn under the national living wages (Savage 2018). The narratives of both Ed and Kai reveal the impossibility of their employment as a gig worker.

\section{Conclusions}

Despite the continuities over time demonstrated by the six narratives as inadequately educated and unskilled young men found themselves restricted to the least desirable and precarious jobs in the service economy, the comparison also reveals changes. The most significant change lies in the impact of the combination of growing insecurity in the labour market with greater uncertainty in family lives, as the restructuring of neo-liberal state demolishes many of the previous safety nets that supported the welfare of the least affluent individuals and households. This coincidence has increased the relative disadvantage of many young men from working class families as the sort of intergenerational support young men in Cambridge and Swindon (Hardgrove et al 2015) were 
able to depend on is being withdrawn as parents struggle with their own problems and reduced living standards (Corlett et al 2018).

While perhaps unable to grasp the complexity of structural forces affecting their lives, the young men in Hastings were both relatively clear sighted and less optimistic about their futures than the earlier respondents. As this latter group suggested, the possibility of securing a job seemed remote and the idea of a future that including housing security completely beyond reach. Indeed, several men among the wider group who were interviewed were pessimistic about even surviving the next decade. They took drugs, engaged in, and sometimes sold, unprotected sex and were often involved in fights. Most of them carried knives. They lived in their parental homes on occasion, but were often evicted; they sofa surfed with friends and sometimes slept rough. For all these reasons they were not seen as suitable employees in the shops, cafes, supermarkets or other casual tourist trades.

While young women typically are less disadvantaged than young men in the same class position in terms of access to the sort of interactive service sector jobs that expanded so rapidly in the 1990s and early 2000s, the position seems to have been reversed in gig economy jobs. Here the majority of workers are young men. However, it seems that a divide is opening between the least skilled and poorest educated young men and those with somewhat more resources and perhaps greater familial support, creating a new division between working class youths, in which a proportion of them remain outside the precariat, identified by the labour economist, Standing (2011) as a new class formation. This emergent class, he suggested, is based on an alliance between the precarious poor, those whom the sociologist Castells (2000) termed generic labourers, and the educated but newly precarious in the knowledge economy, including growing numbers of contract researchers and lecturers in British universities. The young men whose voices are heard here are excluded from even this precarious class. As a consequence, earlier claims about the employment opportunities for less educated and insecure young men and women may need re-evaluation. The relative advantage of young women may be declining as the gig economy expands, and a new divide seems to be opening up between young men: those within the precariat, who may be insecure but at least participate in waged work, and those who are now excluded altogether, by material and personal disadvantage.

\section{Acknowledgements}

Thank you to the young men who talked so freely and to Abby Hardgrove and Esther Rootham who worked with me in Swindon and Anna Harris in Hastings. 
The research was funded by Rowntree (Cambridge) and Leverhulme (Swindon and Hastings).

\section{Conflict of interest statement}

There are no conflicts of interest 


\section{References}

Antonucci, L., M. Hamilton, and S. Roberts,.2015. Young people in Europe: Dealing with Risk, Inequality and Precarity in Time of Crisis. London: Palgrave Macmillan.

Ashton, D., M. Maguire, and M. Spilsbury. 1990. Restructuring the Labour Market: The Implications for Youth. London: Macmillan.

Bauman, Z. 1998. Work, Consumerism and the New Poor. Buckingham: Open University Press

Besen-Cassino, Y. 2014. Consuming Work: Youth Labor in America. Philadelphia: Temple University Press.

Bloodworth, J. 2018. Hired: Six Months Undercover in Low-wage Britain. London: Atlantic Books.

Bourdieu, P. 1997. Outline of a Theory of Practice. Cambridge: Cambridge University Press.

Bourdieu, P. 1999. The Weight of the World. Cambridge: Polity.

Bourgois, P. 1995. In Search of Respect: Selling Crack in El Barrio. Cambridge: Cambridge University Press.

Brooks, R., ed. 2009. Transitions from Education to Work: New Perspectives from Europe and Beyond. Basingstoke: Palgrave Macmillan.

Castells, M. 2000. "Materials for an Exploratory Study of the Network Society". British Journal of Sociology. 51 (1): 5-22.

Connell, R. W. 2000. The Men and the Boys. Cambridge: Polity.

Corfe, S. 2017. Living on the Edge: Britain's Coastal Communities. London: Social Market Foundation.

Corlett, A,. G. Bangham, and D. Finch. 2018. The Living Standards Outlook 2018. London: The Resolution Foundation.

Crang, P, and R. Martin. 1991. "Mrs Thatcher's Britain or the Other Sides of the Cambridge Phenomenon”. Environment and Planning D: Society and Space 9 (2): 91-116.

Day, J. 2016. Cyclogeography: Journeys of a London Bicycle Courier. London: Notting Hill Editions.

Farnsworth, K. 2011. "From Economic Crisis to a New Age of Austerity: the UK". In Social Policy in Challenging Times, edited by Farnsworth, K, and Z. Irving, 252-270. Bristol: Policy Press

Farrugia, D., S. Theadgold, and J. Coffey. 2018. "Young Subjectivities and Affective Labour in the Service Sector. Journal of Youth Studies 21 (3): 272-287.

Fine, M., and L. Weiss. 1998. The Unknown City: The Lives of Poor and Working-class Adults. Boston: Beacon Press. 
Fleming, P. 2017. "The Human Capital Hoax: Work, Debt and Insecurity in the Era of Uberization”. Organization Studies, 38 (6): 691-709.

France, A. 2008. "Being to Becoming: the Importance of Tackling Youth Poverty in Transitions to Adulthood". Social Policy and Society 7 (5): 495-505.

France, A. 2016. Understanding Youth in the Global Economic Crisis. Bristol: Policy Press.

Furlong, A. 2006. "Not a very NEET Solution: Representing Problematic Labour Market Solutions among Early School-leavers”. Work, Employment and Society 20 (6): 553-569.

Giazitzoglu, A. 2014. "Learning not to Labour: A Micro Analysis of Consensual Male Unemployment”. International Journal of Sociology and Social Policy 34 (4): 334-342.

Gilligan, C., R. Spencer, M. Weinberg, and T Bertsch. 2003. "On the listening guide: a voicecentred relational method". In Qualitative Research in Psychology: Expanding Perspectives in Methodology and Design, edited by Comic, P M, J E Rhodes, and L. Yardley. 157-172. Washington D.C.: American Psychological Association Press

Grimshaw, D. and J. Rubery. 2012. "The End of the UK's Liberal Collectivist Model". Cambridge Journal of Economics 36 (1): 105-126.

Grubium, J. F, and J. A. Holstein. 2009. Analysing Narrative Reality Thousand Oaks CA: Sage.

Hardgrove, A., E. Rootham, and L. McDowell. 2015. "Precarious Lives, Precarious labour: Family Support and Young Men's Transitions to Work in the UK". Journal of Youth Studies 18 (8): 1057-76.

Healy, J., D. Nicholson, and A. Pekarek. 2017. "Should We Take the Gig Economy Seriously?" Labour \& Industry: A Journal of the Social and Economic Relations of Work 27 (3): 232-248.

Hochschild, A. 1983. The Managed Heart: Commercialisation of Human Feeling. Berkeley: University of California Press.

Hughes, G., C. Cooper, S. Gormally, and J. Rippingale. 2014. "The State of Youth Work in Austerity England". Youth and Policy 113: 1-14.

Ilan, J. 2013. "Street Social Capital in the Liquid City". Ethnography 14 (1): 3-24.

Jeffrey, C, and J. Dyson. 2008. Telling Young lives: Portraits of Global Youth. Philadelphia: Temple University Press.

Jones, O. 2012. Chavs: the Demonisation of the Working Class. London: Verso.

Kirk, K, and C. Cotton. 2012. The Cambridge Phenomenon: 50 years of innovation and enterprise. London: Third Millennium. 
Lupton, R,. T. Burchardt, J. Hills, K. Stewart, and P. Vizard, eds. 2016. Social Policy in a Cold Climate: Policies and their Consequences since the Crisis. Bristol: Policy Press.

MacDonald, R. 2016. "Precarious Work: The Growing Precarité of youth. In The International Handbook of Youth and Young Adulthood, edited by A. Furlong, 155163. London: Routledge.

McDonald, R. and J. Marsh. 2001. “Disconnected youth?”. Journal of Youth Studies 4 (4): 373-391.

MacDonald, R., T. Shildrick, and S. Black, eds. (2010). Young People, Class and Place. London: Routledge.

McDowell, L. 2003. Redundant Masculinities? Employment Change and White Working Class Youth. Oxford: Blackwell.

McDowell, L. 2012. "Post Crisis, Post Ford and Post Gender? Youth Identities in an Era of Austerity". Journal of Youth Studies 15 (5): 573-590.

Monaghan, L. 2002 “Regulating 'Unruly' Bodies: Work Tasks, Conflict and Violence in Britain's Night-time Economy”. British Journal of Sociology 53 (4): 403-429.

Nayak, A. 2006. Displaced Masculinities: Chavs, youth and Class in the Post-industrial City. Sociology 40 6): 813-831.

Newman, K. 1999. No Shame in My Game: The Working Poor in the Inner City. New York: Russell Sage Foundation and Vintage Books.

Nixon, D. 2009. "I can’t put a Smiley Face on: Working Class Masculinity, Emotional Labour and Service Work in the New Economy". Gender, Work and Organisation 16 (2): 300-322.

Nixon, D. 2017. "Yearning to Labour? Working Class Men in Post-industrial Britain". In Masculinity, Labour and Neoliberalism: Working Class Men inIinternational Perspective edited by C. Walker and S. Roberts, 53-75. London: Palgrave Macmillan.

Prassl, J. 2018. Humans as a Service: Regulating Work in the Gig Economy. Oxford: Oxford University Press.

Rootham, E. and L. McDowell. 2017. "Symbolic Violence and Cruel Optimism: Young Men, Un(der)employment and the Honda Layoffs in Swindon". In Geographies of children and young people - conflict, violence and peace, edited by C. Harker, T. Skelton, and C. Hoschelmann, 1-17. Singapore: Springer.

Savage, M. 2018. "Universal Credit to Slash Benefits for the Self-employed". The Observer 25 March, 14.

Sayarer, J. 2016. Messengers: City Tales from a London Bicycle Courier. London: Arcadia. Sayer, A. 2005. The Moral Economy of Class. Cambridge: Cambridge University Press. 
Silva, J. 2013. Coming Up Short: Working Class Adulthood in an Age of Uncertainty. Oxford: Oxford University Press.

Skeggs, B. 2004. Class, Self, Culture. London: Routledge.

Standing, G. 2011. The Precariat: The New Dangerous Class. London: Bloomsbury.

Taylor, M., G. Marsh, and D. Nicol. 2017. Good Work: The Taylor Review of Modern Working Practices. London: Department for Business, Energy and Industrial Strategy.

Toynbee, P. 2003. Hard Work: Life in Low Pay Britain. London: Bloomsbury.

Valentine, G. and C. Harris. 2014. "Strivers vs Skivers: Class Prejudice and the Demonization of Dependency in Everyday Life". Geoforum 53 (1): 84-92.

Whitman, K. 2017. "Working-class Masculinities at the Nexus of Work, Family and Intimacy in the Age of Neoliberalism". In Masculinity, Labour and Neoliberalism: Working class men in international perspective, edited by C. Walker and S. Roberts, 265-287. London: Palgrave Macmillan.

Williams, C., and C. Connell. 2010. "'Looking Good and Sounding Right': Aesthetic Labour and Social Inequality in the Retail Industry". Work and Occupations 37: 349-377.

Willis, P. 1977 Learning to Labour: How Working Class Kids get Working Class Jobs. Saxon House: London.

Youndell, D. and McGimpsey, I. 2015. “Assembling, Disassembling and Reassembling youth Services in Austerity Britain”. Critical Studies in Education 56 (1): 116-130. 